\title{
Methemoglobinemia and Intravascular Hemolysis; Unusual Presentations of Metal Phosphides Poisoning
}

\author{
Amira A. Wahdan and Enas I. Elmadah ${ }^{1}$ \\ ${ }^{1}$ Department of Forensic Medicine and Clinical Toxicology, Faculty of Medicine, Tanta University, Tanta, Egypt.
}

\begin{abstract}
Introduction: Metal phosphides are highly effective insecticides and rodenticide. They are used as a cheap and effective rodenticide in developing countries. Hemolysis and methemoglobinemia are rare but reported complications of phosphide poisoning

Aim of the work: The aim of this study was to detect the incidence of methemoglobinemia and intravascular hemolysis in some cases of acute phosphide poisoning.

Patients and methods: A cross sectional study was conducted on 50 cases suffering from acute metal phosphide poisoning admitted to Tanta toxicology unit, from the start of October 2014 till the end of March 2015. For each case, the following were done: history taking, physical examination and laboratory investigations (including measurement of methemoglobin (Met-Hb) level, arterial blood gas analysis, routine investigations, lactate dehydrogenase enzyme and complete blood picture with reticulocytic count).

Results: Eight cases (16\%) had combined methemoglobinemia and hemolysis. Aluminum phosphide was the toxic agent in seven of them and zinc phosphide in only one. Three cases (6\%) had methemoglobinemia alone; one of them was poisoned by aluminum phosphide and the other two by zinc phospide. Another three cases had hemolysis alone; one of them was due to aluminum phosphide toxicity and the other two were due to zinc phospidetoxicity. So the present study included a total of eleven cases $(22 \%)$ of methemoglobinemia. Their median age was 27 years old, while it was 24 years for patients with normal Met-Hb level. The median delay time was 4 hours for them and 2 hours for cases with normal Met-Hb level with significant statistical differences between both. The mean Met-Hb level was $14.45 \pm$ $9.32 \%$ and $1.63 \pm 0.45 \%$ in cases with high and normal Met-Hb level respectively, with a significant statistical difference between both. Furthermore, the mean oxygen saturation showed a significant statistical difference between both. In addition, the present study included a total of eleven cases $(22 \%)$ of hemolysis. Their median age was 27 years old, while it was 24 years for patients with no hemolysis. The median delay time was 3 hours in them and 2 hours in cases with no hemolysis.

Conclusion: It was concluded that methemoglobinemia and hemolysis can complicate the course of acute phosphide poisoning.

Recommendations: Further studies on a large scale of cases of acute phosphide poisoning with assessment of the outcome of cases presented with methemoglobinemia and hemolysis and the efficacy of the available treatment for such cases are recommended. Furthermore, it is important that health care professionals be aware of these rare presentations of phosphide poisoning.
\end{abstract}

Keywords Aluminum phosphide, zinc phosphide, poisoning, methemoglobinemia, hemolysis

\section{Introduction}

A cute poisoning with pesticides is a global public health problem and accounts for as many as 300 000 deaths worldwide every year (Goel and Aggarwal, 2007). In Egyptin2006, pesticide poisoning represented $51 \%$ of admitted cases (a total of 21,805 cases) at Ain Shams University. Phosphide poisoning accounted for $20 \%$ of this number(Mansour, 2008). The low price and easy availability of phosphides, make them a common self-poisoning agent in Egypt (El Naggar and El Mahdy, 2011). 
Phosphides are normally found as powders or pellets, usually in the form of zinc or aluminum phosphide (Burkhart, 2006). Phosphine gas (the active form of the pesticide) is released when phosphides mix with moisture in the air or when they come in contact with an acid (Mehrpour et al., 2012). Phosphide compounds have been used as pesticides for many years to protect grains in stores and during its transportation. Acute poisoning with these compounds may be direct due to ingestion of the salts or indirect from accidental inhalation of phosphine generated during their approved use (Proudfoot, 2009).

Once ingested, phosphides are decomposed into highly toxic phosphine gas by the action of dilute hydrochloric acid content of the stomach. Phosphine acts as a respiratory poison (Popp et al., 2002). It inhibits mitochondrial oxidative phosphorylation by inhibition of cytochrome C oxidase enzyme (Singh et al., 2006). It also disturbs the mitochondrial morphology, inhibits oxidative respiration by $70 \%$ and causes a severe drop in mitochondrial membrane potential. Phosphine and hydrogen peroxide can interact to form the highly reactive hydroxyl radical. In addition, phosphine inhibits catalase and peroxidase; both mechanisms result in hydroxyl radical associated damage such as lipid peroxidation (Proudfoot, 2009).

There is a short interval between ingestion of phosphides and the appearance of manifestations of systemic toxicity because of the rapid and easy absorption of phosphine (Stewart et al., 2003). Phosphide poisoning affects most organs including the heart, lungs, kidneys and gastrointestinal tract. Early symptoms include nausea, vomiting, retrosternal and epigastric pain, dyspnea, anxiety, agitation and smell of garlic on breath. Moreover, shock and peripheral circulatory failure are mainly imperative early signs of toxicity (Mostafazadeh, 2012).

Uncommon and rare complications of phosphide poisoning include gastroduodenitis, hepatitis, delayed esophageal stricture, acute tubular necrosis, methemoglobinemia and hemolysis (Lakshmi, 2002; Shadnia and Soltaninejad, 2011). To the best of recent knowledge, only few cases of phosphide poisoning presented with intravascular hemolysis; two of them had glucose 6 phosphate dehydrogenase (G-6-PD) enzyme deficiency (Sood et al., 1997; Srinivas et al., 2007) and the other were with normal G-6-PD enzyme level (Aggarwal et al., 1999; Lakshmi, 2002; Soltaninejad et al., 2011). In addition, methemoglobinemia was recorded in only few cases of phosphide poisoning (Lakshmi, 2002; Lall et al., 2000; Shadnia et al., 2011; Soltaninejad et al., 2011)and there is only one study regarding blood level of methemoglobin (Met-Hb) after phosphide poisoning (Mostafazadeh et al., 2011). So, the aim of the present study was to detect the incidence of methemoglobinemia and intravascular hemolysis in some cases of acute phosphide poisoning.

\section{Patients and methods \\ Study design}

A cross sectional study was conducted on 50 cases suffering from acute metal phosphide (aluminum and zinc) poisoning admitted to toxicology unit, Tanta University Emergency Hospital, from the start of October 2014 till the end of March 2015.

\section{Patients}

Fifty adult patients with history of exposure to, symptoms and/ or signs of acute metal phosphide poisoning and positive result of the silver nitrate test (i.e. the silver nitrate impregnated filter paper turned brownish to black color on exposure to patients' gastric fluid or breath according to Chugh et al. (1989) were included after obtaining an informed written consent from each patient or from one of his first degree relatives for participation. Pregnant females, patients younger than 18 years old, patients who had ingested other substances in addition to the pesticide, and patients with other serious medical conditions (e.g. cardiovascular disease, renal, hepatic, pulmonary or intestinal impairment, bone disease, pancreatitis, diabetes, malignancy and any cause of hemolytic anemia or methemoglobinemia) were excluded from the study. Privacy of the patients and confidentiality of the data were maintained by coding system.

\section{For each patient, the following were done: History taking}

1- Personal history with emphasis on age and gender.

2- Toxicological history including; type of phosphide (aluminum or zinc), mode of poisoning, route of exposure and delay time.

3- Medical history including any serious medical disease with emphasis on blood diseases (e.g. anemia, inherited blood disorders such as G-6PD deficiency, sickle cell anemia and thalassemia)

\section{Physical examination}

Including assessment of consciousness level by Glasgow Coma Scale (GCS), regular monitoring of vital signs (pulse, blood pressure, respiratory rate, and temperature) and general clinical examination with emphasis on signs of hemolytic anemia and methemoglobinemia including pallor, jaundice, cyanosis, rapid or irregular heartbeats, rapid or uneven breathing and bleeding.

\section{Laboratory investigations}

(done immediately after admission and before giving any medications)

- Methemoglobin level was measured by using the Masimo co-oximetry. Methemoglobinemia was diagnosed when Met-Hb level was $\geq$ 3\%(Price, 2006).

- Blood samples were obtained from each patient;

- One milliliter arterial blood for blood gas analysis. 
- Three milliliters venous blood for routine investigations (alanine transaminase, aspartate transaminase, indirect bilirubin, creatinine, blood urea nitrogenand electrolytes) and lactate dehydrogenase (LDH) enzyme level. This venous blood sample was kept into a clean dry centrifuge tube and left to stand for a few hours before centrifugation to avoid hemolysis. Serum was separated and then used for estimation of the biochemical tests.

- Another three milliliters venous blood was obtained for performing complete blood picture (CBC). Blood sample for $\mathrm{CBC}$ was evacuated in EDTA tubes. Gently mixed by inverting the tube 5-10 times and placed on a rocker for up to 30 minutes, then refrigerated at $2-8^{\circ} \mathrm{C}$. Refrigerated EDTA blood is stable for $\mathrm{CBC}$ for up to 24 hours.

Anemia is defined using the hemoglobin $(\mathrm{Hb})$ concentration, although for practical purposes the Hematocrit (HCT) is comparably reliable. According to the laboratory in which these investigations were done, the reference range for $\mathrm{Hb}$ concentration in adult males is 14.0 to $17.5 \mathrm{~g} / \mathrm{dL}$ and in adult females is 12.5 to $15.5 \mathrm{~g} / \mathrm{dL}$. In addition, the reference range for HCT value is $42 \%$ to $50 \%$ in adult males and $36 \%$ to $44 \%$ in adult females.

The most characteristic presentation of hemolysis is reticulocytosis (the normal reticulocyte count by light microscopy is $0.5 \%$ to $1.5 \%$ of the total red cells) with some degree of hyperbilirubinemia (the increased serum bilirubin level in hemolysis almost always consists of the unconjugated pigment).Other markers reflect direct red cell injury e.g., increased serum LDH (Means and Glader, 2014).

\section{Treatment of phosphide poisoning}

Initial stabilization measures and standard supportive care were carried out. Gut decontamination by gastric lavage with sodium bicarbonate solution was done for cases of phosphide ingestion. Symptomatic treatment according to the condition of the case was done.

\section{Statistical analysis}

The collected data were organized and statistically analyzed using SPSS software statistical computer package for windows version 22. For quantitative data, the Shapiro-Wilk test for normality was performed. For data that were not normally distributed median and interquartile range (expressed as 25th-75th percentiles) were calculated and Mann-Whitney $U$ was used for comparison between groups. For normally distributed data, values were expressed as mean \pm standard deviation and independent sample $\mathrm{T}$ test was used for comparison. For qualitative data, Pearson's Chi-square test or Fisher's exact test were calculated. Significance was adopted at $\mathrm{p}<0.05$ for interpretation of results of tests (Dawson-Saunders and Trapp, 2001).

\section{Results}

A total of 50 cases were included. Their ages ranged between 18 and 65 years with a median of 24.5 years. Twenty eight of them were females and 22 were males. Seventy two percent of the cases had ingested phosphides in suicidal attempts and the rest had inhaled them accidentally. Zinc phosphide was identified in 26 $(52 \%)$ cases and aluminum phosphide was identified in $24(48 \%)$ cases. The median delay time was 3 hours (table 1). The clinical presentation is shown in table (2). Metabolic acidosis was present in 16 cases (32\%), while the remaining 34 cases $(68 \%)$ were with normal acid base state. The results of Met-Hb concentration, CBC, indirect bilirubin and LDH are presented in table (3). All the routine investigations (including alanine transaminase, aspartate transaminase, creatinine, blood urea nitrogen and electrolytes) were within normal ranges.

Eight cases (16\%) had combined methemoglobinemia and hemolysis; one of them was a male who had ingested zinc phosphide in suicidal attempt, four were females who had ingested aluminum phosphide in suicidal attempts and the remaining three were males who had inhaled aluminum phosphide accidentally. Their ages ranged between 18 and 53 years with a mean of $31.88 \pm 11.84$ years. The mean delay time was $4.13 \pm 2.1$ hours. Their clinical presentation and investigations are presented in tables $(4 \& 5)$.

Three cases $(6 \%)$ had methemoglobinemia only; one of them was a female who had ingested aluminum phosphide in suicidal attempt and the other two were a male and a female who had ingested zinc phospide also in suicidal attempts. Another three cases had hemolysis only; one of them was a female who had inhaled aluminum phosphide accidentally and the other two were females who had ingested zinc phospide in suicidal attempts.

Based on the above results, the present study included eleven cases (22\%) of methemoglobinemia. The median age for them was 27 years old, while it was 24 years for patients with normal Met-Hb level. The median delay time was 4 hours in cases with methemoglobinemia and 2 hours in cases with normal Met-Hb level. As regards the demographic data and toxicological history, there were no significant statistical differences between cases with high and normal Met-Hb level except for the median delay time (table 6). The mean Met-Hb level was14.45 $\pm 9.32 \%$ and $1.63 \pm 0.45 \%$ in cases with high and normal Met-Hb level respectively, with a significant statistical difference between both. The mean oxygen saturation was 91.36 $\pm 5.73 \%$ and $97.76 \pm 2.39 \%$ in cases with high and normal Met-Hb level respectively, also with a significant statistical difference between both. The clinical manifestations of cases with methemoglobinemia were vomiting (in 72.7\%), abdominal pain (in 36.4\%), dyspnea (in 63.6\%), dizziness (in 27.3\%), hypotension (in 36.4\%), pallor (in 9.2\%), pallor with cyanosis (in 
$45.5 \%$ ) and pallor with cyanosis and jaundice (in $27.3 \%)$.Seven (63.6\%)out of the eleven cases of methemoglobinemia had metabolic acidosis and the remaining four $(36.4 \%)$ were with normal acid base state, while in the thirty nine cases with normal Met-Hb level, thirty $(76.9 \%)$ cases were with normal acid base state and only nine (23.1\%) had metabolic acidosis. There was a significant statistical difference between cases with normal and high Met-Hb level as regards the acid base state.

In addition, the present study included eleven cases $(22 \%)$ with hemolysis. Also the median age for them was 27 years old, while it was 24 years for patients with no hemolysis. The median delay time was 3 hours in cases with hemolysis and 2 hours in cases with no hemolysis. There was no significant statistical difference between cases with hemolysis and no hemolysis regarding all demographic data and toxicological history (table 7). The clinical manifestations of cases with hemolysis were vomiting (in $81.8 \%$ ), abdominal pain (in $27.3 \%$ ), dyspnea (in 63.6\%), dizziness (in 27.3\%), hypotension (in $36.4 \%$ ), pallor (in $18.2 \%$ ), pallor with cyanosis (in 45.5\%) and pallor with cyanosis and jaundice (in 27.3\%). Results for laboratory investigations of cases with hemolysis and cases with no hemolysis are shown in table (8). The result of ABG analysis for cases with hemolysis was similar to those for cases with methemoglobinemia. Also there was a significant statistical difference between cases with hemolysis and cases with no hemolysis as regards the acid base state.

Table 1: Distribution of demographic data (age and gender) and toxicological history of cases intoxicated by phosphides ( 50 cases)

\begin{tabular}{|c|c|c|c|}
\hline \multirow{2}{*}{ Age (years) } & \multicolumn{2}{|l|}{ Median } & 24.5 \\
\hline & \multicolumn{2}{|l|}{ IQR } & 11 \\
\hline \multirow[t]{4}{*}{ Gender } & \multirow[t]{2}{*}{ Female } & $\mathrm{n}$ & 28 \\
\hline & & $\%$ & 56 \\
\hline & \multirow[t]{2}{*}{ Male } & $\mathrm{n}$ & 22 \\
\hline & & $\%$ & 44 \\
\hline \multirow[t]{4}{*}{ Mode of poisoning } & \multirow[t]{2}{*}{ Accidental } & $\mathrm{n}$ & 14 \\
\hline & & $\%$ & 28 \\
\hline & \multirow[t]{2}{*}{ Suicidal } & $\mathrm{n}$ & 36 \\
\hline & & $\%$ & 72 \\
\hline \multirow[t]{4}{*}{ Route of exposure } & \multirow[t]{2}{*}{ Ingestion } & $\mathrm{n}$ & 36 \\
\hline & & $\%$ & 72 \\
\hline & \multirow[t]{2}{*}{ Inhalation } & $\mathrm{n}$ & 14 \\
\hline & & $\%$ & 28 \\
\hline \multirow[t]{2}{*}{ Delay (Hours) } & \multicolumn{2}{|l|}{ Median } & 3.00 \\
\hline & \multicolumn{2}{|l|}{ IQR } & 2.00 \\
\hline
\end{tabular}

$n=$ number, $I Q R=$ inter quartile range

Table 2: Distribution of clinical presentation of cases intoxicated by phosphides ( 50 cases)

\begin{tabular}{|c|c|c|c|}
\hline \multicolumn{2}{|c|}{ Clinical presentation } & n & $\%$ \\
\hline \multicolumn{2}{|c|}{ Asymptomatic } & 4 & 8 \\
\hline \multicolumn{2}{|l|}{ Vomiting } & 37 & 74 \\
\hline \multicolumn{2}{|c|}{ Abdominal colic } & 19 & 38 \\
\hline \multicolumn{2}{|l|}{ Dyspnea } & 9 & 18 \\
\hline \multicolumn{2}{|l|}{ Dizziness } & 6 & 12 \\
\hline \multicolumn{2}{|c|}{ Hypotension } & 9 & 18 \\
\hline \multicolumn{2}{|c|}{ Tachycardia } & 16 & 32 \\
\hline \multirow[t]{4}{*}{ Skin color } & Normal & 33 & 66 \\
\hline & Pallor & 8 & 16 \\
\hline & Pallor+ cyanosis & 6 & 12 \\
\hline & Pallor+ cyanosis + jaundice & 3 & 6 \\
\hline \multirow{2}{*}{\multicolumn{2}{|c|}{ GCS }} & Median & 15 \\
\hline & & Range & 3- 15 \\
\hline
\end{tabular}

n=number, $G C S=$ Glasgow coma scale 
Table 3: Laboratory investigation of cases intoxicated by phosphides ( 50 cases)

\begin{tabular}{|l|c|c|}
\hline Investigation & Mean & \pm SD \\
\hline Methemoglobin concentration (\%) & 4.45 & 6.83 \\
\hline Oxygen saturation & $96.36 \%$ & $4.28 \%$ \\
\hline Hemoglobin concentration (gm/dL) & 11.59 & 2.22 \\
\hline Red blood cell count & $4.41 \times 10^{6}$ & $0.72 \times 10^{6}$ \\
\hline HCT (\%) & 39.14 & 6.21 \\
\hline MCV (fL) & 88.90 & 6.17 \\
\hline MCH (pg) & 26.55 & 2.72 \\
\hline MCHC (\%) & 29.85 & 3.36 \\
\hline Reticulocytic count & 88884 & 52021.09 \\
\hline Platelet count & 212320 & 57684 \\
\hline Indirect bilirubin (mg/dL) & 0.91 & 0.63 \\
\hline Lactate dehydrogenase enzyme (IU/L) & 245.14 & 65.68 \\
\hline
\end{tabular}

$S D=$ standard deviation, $H C T=$ hematocrit value, $M C V=$ Mean corpuscular volume, $M C H=$ Mean corpuscular hemoglobin, $M C H C=$ Mean corpuscular hemoglobin concentration, gm/dL= grams/deciliter, $f L=$ femtoliters/cell, $p g=$ picograms/cell, $\mathrm{mg} /$ dL = milligrams/deciliter, IU/L= international unit per liter

Table 4: Clinical presentation of cases of combined methemoglobinemia and hemolysis ( 8 cases)

\begin{tabular}{|c|c|c|c|}
\hline \multicolumn{2}{|c|}{ Clinical presentation } & $\mathbf{n}$ & $\%$ \\
\hline \multicolumn{2}{|l|}{ Vomiting } & 6 & 75 \\
\hline \multicolumn{2}{|c|}{ Abdominal colic } & 3 & 37.5 \\
\hline \multicolumn{2}{|l|}{ Dyspnea } & 7 & 87.5 \\
\hline \multicolumn{2}{|l|}{ Dizziness } & 3 & 37.5 \\
\hline \multicolumn{2}{|l|}{ Hypotension } & 4 & 50 \\
\hline \multicolumn{2}{|l|}{ Tachycardia } & 4 & 50 \\
\hline \multirow[t]{2}{*}{ Skin color } & Pallor+ cyanosis & 5 & 62.5 \\
\hline & Pallor+ cyanosis+ jaundice & 3 & 37.5 \\
\hline \multirow[t]{2}{*}{ Acid base state } & Normal & 2 & 25 \\
\hline & Metabolic acidosis & 6 & 75 \\
\hline \multirow{2}{*}{\multicolumn{2}{|c|}{ GCS }} & Mean & 8.63 \\
\hline & & $\pm \mathrm{SD}$ & 4.87 \\
\hline
\end{tabular}

n=number, GCS= Glasgow coma scale

Table 5: Laboratory investigations of cases of combined methemoglobinemia and hemolysis ( 8 cases)

\begin{tabular}{|l|r|r|r|r|}
\hline Investigation & \multicolumn{1}{|c|}{ Minimum } & \multicolumn{1}{|c|}{ Maximum } & \multicolumn{1}{c|}{ Mean } \\
\hline Methemoglobin concentration (\%) & 18 & 25 & 21 & 2.71 \\
\hline Oxygen saturation & 84 & 90 & 87.43 & 2.15 \\
\hline Hemoglobin concentration (gm/dL) & 6.5 & 9 & 7.57 & 0.93 \\
\hline RBCs & $3 \times 10^{6}$ & $3.5 \times 10^{6}$ & $3.24 \times 10^{6}$ & $0.17 \times 10^{6}$ \\
\hline HCT (\%) & 22 & 34 & 28.43 & 3.55 \\
\hline MCV (fL) & 68.75 & 100 & 87.61 & 10.02 \\
\hline MCH (pg) & 20.5 & 28 & 23.57 & 2.89 \\
\hline MCHC (\%) & 22.5 & 36 & 27.43 & 5.34 \\
\hline Reticulocytic count & 16000 & 210000 & 174757.14 & 16864.74 \\
\hline Platelet & 65 & 220 & 145 & 59.65 \\
\hline Indirectbilirubin (mg/dL) & 1.8 & 2.8 & 2.29 & 0.46 \\
\hline LDH (IU/L) & 310 & 375 & 341.43 & 24.95 \\
\hline
\end{tabular}

$S D=$ standard deviation, $H C T=$ hematocrit value, $M C V=$ Mean corpuscular volume, $M C H=$ Mean corpuscular hemoglobin, $M C H C=$ Mean corpuscular hemoglobin concentration, gm/dL= grams/deciliter, $f L=$ femtoliters/cell, $p g=$ picograms/cell, $\mathrm{mg} / \mathrm{dL}=$ milligrams/deciliter, $I U / L=$ international unit per liter 
Table 6: Correlation between presence or absence of methemoglobinemia with demographic data and toxicological history

\begin{tabular}{|c|c|c|c|c|c|c|}
\hline & & & Methe & globinemia & & \\
\hline & & & Present $(n=11)$ & Absent $(n=39)$ & $\begin{array}{l}\text { Test } \\
\text { statistic }^{\text {a }}\end{array}$ & $P$ value \\
\hline Age & Median & & 27 & 24 & 152.5 & 0.145 \\
\hline & IQR & & 19 & 10 & & \\
\hline Gender & Female & $\mathrm{N}$ & 6 & 22 & 0.012 & 0.912 \\
\hline & & $\%$ & 54.5 & 56.4 & & \\
\hline & Male & $\mathrm{N}$ & 5 & 17 & & \\
\hline & & $\%$ & 45.5 & 43.6 & & \\
\hline Rodenticide & Zinc phosphide & $\mathrm{N}$ & 3 & 23 & 3.445 & 0.06 \\
\hline & & $\%$ & 27.3 & 58.97 & & \\
\hline & Aluminum Phosphide & $\mathrm{N}$ & 8 & 16 & & \\
\hline & & $\%$ & 72.7 & 41.03 & & \\
\hline Route of exposure & Ingestion & $\mathrm{N}$ & 8 & 28 & 0.004 & 0.951 \\
\hline & & $\%$ & 72.7 & 71.8 & & \\
\hline & Inhalation & $\mathrm{N}$ & 3 & 11 & & \\
\hline & & $\%$ & 27.3 & 28.2 & & \\
\hline Mode of poisoning & Accidental & $\mathrm{N}$ & 3 & 11 & 0.004 & 0.951 \\
\hline & & $\%$ & 27.3 & 28.2 & & \\
\hline & Suicidal & $\mathrm{N}$ & 8 & 28 & & \\
\hline & & $\%$ & 72.7 & 71.8 & & \\
\hline Delay (hours) & Median & & 4 & 2 & 103.5 & $0.008 *$ \\
\hline & IQR & & 2 & 1.5 & & \\
\hline
\end{tabular}

${ }^{a}:$ Mann Whitney $U$ test for age and delay; Chi square test for sex, route and circumstances, * Significant at $p<0.05$., $n=$ number, IQR= inter quartile range

Table 7: Correlation between presence or absence of hemolysis with demographic data and toxicological history

\begin{tabular}{|c|c|c|c|c|c|c|}
\hline \multirow{2}{*}{\multicolumn{3}{|c|}{ 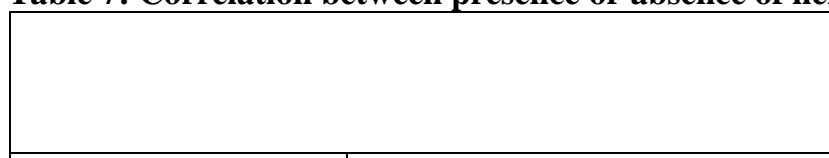 }} & \multicolumn{2}{|c|}{ Hemolysis } & \multirow[b]{2}{*}{ Test statistic $^{a}$} & \multirow[b]{2}{*}{ P value } \\
\hline & & & $\begin{array}{l}\text { Present } \\
(n=11)\end{array}$ & \begin{tabular}{|l} 
Absent \\
$(\mathrm{n}=39)$
\end{tabular} & & \\
\hline \multirow[t]{2}{*}{ Age } & \multicolumn{2}{|l|}{ Median } & 27 & 24 & \multirow[t]{2}{*}{1.059} & \multirow[t]{2}{*}{0.290} \\
\hline & \multicolumn{2}{|l|}{ IQR } & 21 & 10 & & \\
\hline \multirow[t]{4}{*}{ Gender } & \multirow[t]{2}{*}{ Female } & $\mathrm{n}$ & 7 & 21 & \multirow[t]{4}{*}{0.055} & \multirow[t]{4}{*}{0.815} \\
\hline & & $\%$ & 63.6 & 53.8 & & \\
\hline & \multirow[t]{2}{*}{ Male } & $\mathrm{n}$ & 4 & 18 & & \\
\hline & & $\%$ & 36.4 & 46.2 & & \\
\hline \multirow[t]{4}{*}{ Rodenticide } & \multirow[t]{2}{*}{ Zinc phosphide } & $\mathrm{n}$ & 3 & 23 & \multirow[t]{4}{*}{3.445} & \multirow[t]{4}{*}{0.06} \\
\hline & & $\%$ & 27.3 & 58.97 & & \\
\hline & \multirow[t]{2}{*}{ Aluminum phosphide } & $\mathrm{n}$ & 8 & 16 & & \\
\hline & & $\%$ & 72.7 & 41.03 & & \\
\hline \multirow[t]{4}{*}{\begin{tabular}{|l} 
Route of exposure \\
\end{tabular}} & \multirow[t]{2}{*}{ Ingestion } & $\mathrm{n}$ & 7 & 29 & \multirow[t]{4}{*}{0.102} & \multirow[t]{4}{*}{0.749} \\
\hline & & $\%$ & 63.6 & 74.4 & & \\
\hline & \multirow[t]{2}{*}{ Inhalation } & $\mathrm{n}$ & 4 & 10 & & \\
\hline & & $\%$ & 36.4 & 25.6 & & \\
\hline \multirow{4}{*}{$\begin{array}{l}\text { Mode of } \\
\text { poisoning }\end{array}$} & \multirow[t]{2}{*}{ Accidental } & $\mathrm{n}$ & 4 & 10 & \multirow[t]{4}{*}{0.102} & \multirow[t]{4}{*}{0.749} \\
\hline & & $\%$ & 36.4 & 25.6 & & \\
\hline & \multirow[t]{2}{*}{ Suicidal } & $\mathrm{n}$ & 7 & 29 & & \\
\hline & & $\%$ & 63.6 & 74.4 & & \\
\hline \multirow[t]{2}{*}{ Delay (hours) } & \multicolumn{2}{|l|}{ Median } & 3 & 2 & \multirow[t]{2}{*}{-1.245} & \multirow[t]{2}{*}{0.213} \\
\hline & \multicolumn{2}{|l|}{ IQR } & 4 & 1 & & \\
\hline
\end{tabular}

${ }^{a}:$ Mann Whitney $U$ test for age and delay; Chi square test for sex, route and circumstances., $n=$ number, IQR= inter quartile range 
Table 8: Correlation between presence or absence of hemolysis with results of laboratory investigations

\begin{tabular}{|c|c|c|c|c|c|c|}
\hline & \multicolumn{4}{|c|}{ Hemolysis } & \multirow[b]{3}{*}{ Test statistic $^{a}$} & \multirow[b]{3}{*}{ P value } \\
\hline & \multicolumn{2}{|c|}{ Present $(n=11)$} & \multicolumn{2}{|c|}{ Absent $(n=39)$} & & \\
\hline & Mean & $\pm \mathbf{S D}$ & Mean & \pm SD & & \\
\hline $\begin{array}{l}\text { Hemoglobin concentration } \\
(\mathrm{gm} / \mathrm{dL})\end{array}$ & 8.40 & 1.57 & 12.48 & 1.40 & -8.28 & $<0.001 *$ \\
\hline Red blood cell count & 3.31 & 0.24 & 4.72 & 0.44 & -13.54 & $<0.001^{*}$ \\
\hline $\mathrm{HCT}(\%)$ & 29.54 & 3.95 & 41.84 & 3.39 & -10.24 & $<0.001^{*}$ \\
\hline MCV (fL) & 88.93 & 8.38 & 88.89 & 5.53 & 0.017 & 0.98 \\
\hline $\mathrm{MCH}(\mathrm{pg})$ & 25.59 & 3.84 & 26.81 & 2.30 & -1.006 & 0.334 \\
\hline $\mathrm{MCHC}(\%)$ & 29.00 & 4.96 & 30.08 & 2.79 & -0.69 & 0.501 \\
\hline Platelet count & 156.82 & 50.90 & 227.97 & 49.65 & -4.17 & $<0.001 *$ \\
\hline Reticulocytic count & 156672.7 & 33401.4 & 71717.9 & 81633.9 & -4.551 & $<0.001 *$ \\
\hline Reticulocytic percent & 4.76 & 1.12 & 1.15 & 0.3 & 10.578 & $<0.001 *$ \\
\hline Indirect bilirubin $(\mathrm{mg} / \mathrm{dL})$ & 1.87 & 0.75 & 0.64 & 0.12 & -4.42 & $<0.001 *$ \\
\hline $\begin{array}{l}\text { Lactate dehydrogenase enzyme } \\
\text { (IU/L) }\end{array}$ & 310.00 & 66.06 & 226.84 & 53.40 & 4.32 & $<0.001 *$ \\
\hline
\end{tabular}

a: Mann Whitney U test used for comparison of indirect bilirubin and reticulocytic count and independent $\mathrm{T}$ test for comparison of other variables, * Significant at $\mathrm{p}<0.05, \mathrm{SD}=$ standard deviation, $\mathrm{HCT}=$ hematocrit value $\mathrm{MCV}=\mathrm{Mean}$ corpuscular volume, $\mathrm{MCH}=$ Mean corpuscular hemoglobin, $\mathrm{MCHC}=$ Mean corpuscular hemoglobin concentration, gm/dL= grams/deciliter, $\mathrm{fL}=$ femtoliters/cell, $\mathrm{pg}=$ picograms/cell, $\mathrm{mg} / \mathrm{dL}=$ milligrams/deciliter, $\mathrm{IU} / \mathrm{L}=$ international unit per liter

\section{Discussion}

Phosphide intoxication is common in some countries such as India, Iran and Egypt due to easy access to this pesticide. It is used frequently as fumigant and rodenticide (Shadnia et al., 2009).

In the current study, a total of 50 cases of acute zinc and aluminum phosphide poisoning were included. Their ages ranged between 18 and 65 years with a median of 24.5. Fifty eight percent of them were female. These findings were in partial agreement with Mashayekhian et al. (2016) from Iran, who found that the mean age of their study cases was $24.7 \pm 9.6$ years(range: $12-83$ years) and that females accounted for $55.2 \%$ of them. On the other hand the results of the current study disagreed with those of Hassanian-Moghaddam et al. (2014) from Iran, who found that the mean age of their study cases was $29.6 \pm 11.1$ years (range: $15-74$ years) and that $61.2 \%$ of them were male. The female preponderance in the current study may be caused by the higher stress in women's life and their tendency to prefer suicide attempt as a way of salvation.

Seventy two percent of cases included in the present study ingested phosphides intentionally in suicidal attempts and the rest inhaled them accidentally. Zinc phosphide was identified in $52 \%$ of cases and aluminum phosphide in $48 \%$ of cases. These finding were different from results of Shahin et al. (2016) from Egypt (Tanta) who found that $96.6 \%$ of their study patients ingested phosphides in suicidal attempts, while only $3.4 \%$ inhaled them accidentally. In addition, they identified zinc phosphide in $75.9 \%$ of patients and aluminum phosphide in $24.1 \%$ of patients. Generally, the increased number of suicidal attempts may be due to many factors such as financial problems, unemployment, marital conflicts and break-up in the family support system.
The median delay time was 3 hours. This was in agreement with Shahin et al. (2016) who found that the median pre-hospital period in their study was 2 hours. The short duration between exposure and arrival to the hospital in the studied cases could be explained by the presence of the Tanta toxicology unit in the center of Delta region with easy access and readily available transportations. In addition, most of the cases who attempted suicide did not actually intend to end their lives but they just try to draw attention and gain sympathy and help from their families, so they rapidly seek medical support.

The present study revealed that $8 \%$ of cases were asymptomatic. Gastrointestinal (in the form of vomiting and abdominal colic) and cardiovascular manifestations (in the form of tachycardia and hypotension) were the most common presentation of the studied cases (they were present in $74 \%, 38 \%, 32 \%$, and $18 \%$ of cases respectively). Other manifestations included dyspnea in $18 \%$ and dizziness in $12 \%$ of the studied cases. Hosseinian et al. (2011)from Iran and Vijayanath et al. (2011) from India reported that the most common manifestations of patients with aluminium phosphide poisoning were nausea, vomiting and abdominal pain. Furthermore,Puneet et al. (2011) from India reported that shock was present in majority of their study cases.

On the other hand, these findings were comparable to that of El Naggar and El Mahdy (2011) from Egypt (Cairo) who found that $24.2 \%$ of their study patients were asymptomatic, while $36.4 \%, 29.1 \%$ and $10.3 \%$, presented with minor, moderate and major symptoms respectively. Minor symptoms were in the form of GIT manifestations (epigastric pain, nausea or vomiting); moderate symptoms included respiratory 
manifestations (dyspnea and excessive secretions) in addition and major symptoms involved signs of effects on other systems (tachycardia and hypotension, agitation, hallucinations and depression).

In the current study, the GCS ranged between 3 and 15 with a median of 15 . This result was in a partial agreement with Shahin et al. (2016)who found that GCS of their study patients ranged between 6 and 15with a median of 14. GCS might be an indicator of CNS affection by phosphide intoxication (Guale et al., 1994).

In the present study the routine investigations (alanine transaminase, aspartate transaminase, electrolytes, creatinine and blood urea nitrogen) of the studied cases were within normal ranges. Similar results were reported by Sagah et al. (2015) from Egypt (Tanta). In contrast, El Naggar and El Mahdy (2011) reported elevation of ALT, AST and urea level in $28.5 \%, 42.8 \%$ and $2.4 \%$ of their study patients respectively. They also reported some electrolyte disturbances in the form of decreased sodium levels and potassium levels in 50\% and $25 \%$ of patients respectively, which may be due to repeated vomiting.

Metabolic acidosis was present in $32 \%$ of cases included in this study, while the remaining cases were with normal acid base state. This finding was different from results obtained by El Naggar and El Mahdy (2011) who reported wide range of acid base abnormalities including metabolic acidosis in $11.5 \%$ of cases, respiratory acidosis in $10.3 \%$, respiratory alkalosis in $18.4 \%$ and mixed metabolic acidosis and respiratory alkalosis in $26.5 \%$, while only $33.3 \%$ of cases were metabolically stable. In additionJaiswal et al. (2009) from India found that all cases included in their study had metabolic acidosis.

In the present study, eleven cases (22\%) had methemoglobinemia (Met-Hb level $\geq 3 \%$ according to Price (2006). Aluminum phosphide was the type of metal phosphide used by 8 of them, while zinc phosphide was used only by three. Methemoglobinemia after phosphide intoxication is a rare event, and to the best of recent knowledge, it was recorded in only few cases of aluminum phosphide poisoning (Lakshmi, 2002; Lall et al., 2000; Shadnia et al., 2011; Soltaninejad et al., 2011). It was not recorded with zinc phosphide poisoning before. Methemoglobinemia occurs when an abnormal proportion of the iron in heme moiety of the $\mathrm{Hb}$ is oxidized to the ferric state, this leads to impaired oxygen transport and anemic hypoxia which causes shifting of the oxygen dissociation curve to the left (Shadnia et al., 2006).

The etiology of methemoglobinemia may be either a genetic defect in red cell metabolism or $\mathrm{Hb}$ structure or acquired following the oxidative stress of a variety of drugs and toxins. Arsine is one of the oxidant toxins that is known to induce severe methemoglobinemia (Curry, 2005). Phosphine and arsine are chemically very similar, thus occurrence of methemoglobinemia by both of them is expected. The other mechanism of action of phosphine-induced methemoglobinemia is induction of free radicals (Lall et al., 1997).

The mean Met-Hb level was significantly high in cases with methemoglobinemia $(14.45 \pm 9.32 \%)$ in comparison with cases with normal Met-Hb level $(1.63 \pm$ $0.45 \%$ ). The only study that measured the Met-Hb level in blood was done byMostafazadeh et al. (2011) from Iran. They found a correlation between Met-Hb level and the mortality rate where the survivors in their study had a lower blood level of Met-Hb $(2.4 \% \pm 7.1 \%$ versus $15.2 \% \pm 13.5 \%$ in non survivors).

Clinical features of methemoglobinemia depend on the Met-Hb levels in blood. The discoloration of blood and appearance of cyanosis manifest when the Met-Hb levels reach15\%- 20\%. Levels between $20 \%$ and $50 \%$ are associated with dyspnea, fatigue, lethargy, dizziness and headaches. Methemoglobin levels over $50 \%$ are usually associated with CNS depression, seizures and cardiac arrhythmias (Price, 2006; Schonwald, 2001). As the Met-Hb level in the current study did not exceed $25 \%$, the clinical manifestations of methemoglobinemia only included dyspnea (in 63.6\%), dizziness (in 27.3\%) and cyanosis (either alone or with pallor and jaundice in $72.7 \%$ ). Clinical manifestations of methemoglobinemia are due to decreased $\mathrm{O}_{2}$ carrying capacity of $\mathrm{Hb}$ and the consequent tissue hypoxia that contributes to further deterioration of patient's condition (Chui et al., 2005).

In the current study, there was a significant statistical difference between the mean oxygen saturation in cases with high and normal Met-Hb level (91.36 $\pm 5.73 \%$ and $97.76 \pm 2.39 \%$ respectively). Methemoglobinemia should be suspected in the presence of central cyanosis and low oxygen saturation on pulse oximetry in the absence of more prevalent causes of hypoxia such as cardiopulmonary dysfunctions (Baraka et al., 2005). In addition, it is important to mention that generalized cyanosis in the presence of normal arterial oxygen tension and the failure of the cyanosis to resolve with oxygen therapy is an important diagnostic clue of methemoglobinemia (Curry, 2005). Diagnosis is confirmed with multiple wavelength cooximetry (Shadnia et al., 2011).

Eleven cases $(22 \%)$ of the present study had hemolysis. Aluminum phosphide was the type of metal phosphide used by 8 of them, while zinc phosphide was used only by three. Intravascular hemolysis following aluminum phosphide poisoning has been reported in the setting of G-6-PD deficiency (Sood et al., 1997; Srinivas et al., 2007) as well as individuals with normal level of G-6-PD (Aggarwal et al., 1999; Lakshmi, 2002; Soltaninejad et al., 2011). It was not reported previously with zinc phosphide poisoning. Intravascular hemolysis after phosphides poisoning may be caused by their oxidizing properties. Phosphides can oxidize $\mathrm{Hb}$ protein, precipitating it as Heinz bodies, and finally result in intravascular hemolysis (Lakshmi, 2002). In addition, phosphine gas may produce lipid peroxidation which can disturb the integrity of the cells and lead to massive cell 
damage. This may produce hemolysis due to damage to the red cell membrane (Aggarwal et al., 1999; Chugh et al., 1995).

Pallor (in $91.9 \%$ either alone or with cyanosis and jaundice) and jaundice (in 27.3\%) were the most important clinical manifestations of cases with hemolysis. Jaundice due to hepatic damage may occur in a few cases with phophide poisoning (Chittora et al., 1994). This could be related to persistent hypoperfusion of the liver, although a direct toxic effect is also likely. However, in the current study, jaundice was due to intravascular hemolysis, as evidenced by a predominant indirect hyperbilirubinemia, elevated LDH enzyme, and reticlucytosis with normal liver enzymes level. Thus jaundice in patients with phosphide poisoning can be independent of hepatic damage.

In the above cases of methemoglobinemia and hemolysis, there was an overlap in eight cases, so eight cases $(16 \%)$ with combined methemoglobinemia and hemolysis were diagnosed. Combined methemoglobinemia and hemolysis as a clinical presentation of phosphide poisoning was reported previously by Lakshmi (2002), Shadnia et al. (2011), Soltaninejad et al. (2011) in their case reports of aluminum phosphide poisoning. Therefore, it is important that health care professionals be aware of these rare presentations of phosphide poisoning.

It is to be mentioned that there are certain limitations in the current study. First, the study was performed on a small number of cases. In addition, possible errors in taking history from patients or their family members may be a potential limitation. Finally, the outcome of cases included in the study was not assessed.

\section{Conclusion}

The present study concluded that methemoglobinemia and hemolysis can complicate the course of phosphide poisoning.

\section{Recommendations}

Further studies on a large scale of cases with acute phosphide poisoning are recommended.In addition, assessment of the outcome of cases presented with methemoglobinemia and hemolysis and the efficacy of the available treatment for such cases is required. Furthermore, it is important that health care professionals be aware of these rare presentations of phosphide poisoning.

\section{References}

Aggarwal P, Handa R, Wig N et al., (1999): Intravascular hemolysis in aluminium phosphide poisoning. Am J Emerg Med. 17: 488-489.

Baraka AS, Ayoub CM, Yazbeck-Karam V et al., (2005): Prophylactic methylene blue in a patient with congenital methemoglobinemia. Can J Anaesth. 52: $258-261$.

Burkhart KK (2006): Methyl bromide and other fumigants. In: Goldfrank's toxicologic emergencies. Flomenbaum NE, Goldfrank LR,
Hoffman RS et al., (eds), 8th ed., McGraw-Hill, New York, pp: 1556-1563.

Chittora MD, Meena SR, Gupta DK et al., (1994): Acute hepatic failure in aluminium phosphide poisoning. J Assoc Physicians India. 42: 924.

Chugh SN, Ram S, Chugh K et al., (1989): Spot diagnosis of aluminium phosphide ingestion: An application of a simple test. J Assoc Physicians India. 37: 219-220.

Chugh SN, Mittal A, Seth S et al., (1995): Lipid peroxidation in acute aluminium phosphide poisoning. J Assoc Physicians India. 43: 265266.

Chui JS, Poon WT, Chan KC et al., (2005): Nitriteinduced methaemoglobinaemia - aetiology, diagnosis and treatment. Anaesthesia. 60: 496500.

Curry SC (2005): Hematologic syndromes: Hemolysis, methemoglobinemia, sulfhemoglobinemia. In: Critical care toxicology, diagnosis and management of the critically poisoned patient. Brent J, Wallace KL and Burkhart KK (eds), Elsevier Mosby Inc, Philadelphia, pp: 336-341.

Dawson-Saunders B and Trapp R (2001): Basic and clinical biostatics. Dawson-Saunders $\mathrm{B}$ and Trapp R (eds), 3rd ed., McGrow Hill McGrow Hill Medical Publishing Division, pp: 161-218.

El Naggar AM and El Mahdy NM (2011): Zinc phosphide toxicity with a trial of tranexamic acid in its management. Journal of Advanced Research. 2: 149-156.

Goel A and Aggarwal P (2007): Pesticide poisoning. The National Medical Journal of India 20: 182-191.

Guale FG, Stair EL, Johnson BW et al., (1994): Laboratory diagnosis of zinc phosphide poisoning. Vet Hum Toxicol. 36: 517-519.

Hassanian-Moghaddam H, Shahnazi M, Zamani N et al., (2014): Plain abdominal radiography: A powerful tool to prognosticate outcome in patients with zinc phosphide poisoning. Clin Radiol. 69: 1062-1065.

Hosseinian A, Pakravan N, Rafiei A et al., (2011): Aluminum phosphide poisoning known as rice tablet: A common toxicity in north iran. Indian $\mathrm{J}$ Med Sci. 65: 143-150.

Jaiswal S, Verma RK and Tewari N (2009): Aluminum phosphide poisoning: Effect of correction of severe metabolic acidosis on patient outcome. Indian J Crit Care Med. 13: 21-24.

Lakshmi B (2002): Methemoglobinemia with aluminum phosphide poisoning. Am J Emerg Med. 20: 130-132.

Lall SB, Peshin SS and Mitra S (2000): Methemoglobinemia in aluminium phosphide poisoning in rats. Indian J Exp Biol. 38: 95-97.

Lall SB, Sinha K, Mittra S et al., (1997): An experimental study on cardiotoxicity of aluminium phosphide. Indian J Exp Biol. 35: 1060-1064. 
Mansour SA (2008): Environmental impact of pesticides in egypt. Rev Environ Contam Toxicol. 196: 151.

Mashayekhian M, Hassanian-Moghaddam H, Rahimi M et al., (2016): Elevated carboxyhemoglobin concentrations by pulse co-oximetry is associated with severe aluminium phosphide poisoning. Basic Clin Pharmacol Toxicol. doi: 10.1111 [ahead of print]

Means RT and Glader B (2014): Anemia: General considerations. In: Wintrobe's clinical hematolog. Greer JP, Arber DA, Glader B et al., (eds), 13th ed., Lippincott Williams \& Wilkins, Philadelphia, pp: 587-610.

Mehrpour O, Jafarzadeh M and Abdollahi M (2012): A systematic review of aluminium phosphide poisoning. Arh Hig Rada Toksikol. 63: 61-73.

Mostafazadeh B (2012): Aluminium phosphide poisoning. In: Toxicity and drug testing Acree W (eds), InTech, Croatia pp: 348.

Mostafazadeh B, Pajoumand A, Farzaneh E et al., (2011): Blood levels of methemoglobin in patients with aluminum phosphide poisoning and its correlation with patient's outcome. J Med Toxicol. 7: 40-43.

Popp W, Mentfewitz J, Gotz R et al., (2002): Phosphine poisoning in a german office. Lancet. 359: 1574.

Price D (2006): Methemoglobin inducers. In: Goldfrank's toxicologic emergencies. Hoffman RS, Nelson LS, Howland MA et al., (eds), 8th ed., The McGraw-Hill, New York, pp: 17341744.

Proudfoot AT (2009): Aluminium and zinc phosphide poisoning. Clin Toxicol (Phila). 47: 89-100.

Puneet K, Dalal JS, Multani AS et al., (2011): The study of aluminium phosphide poisoning in a tertiary care hospital, Amritsar. Journal of Indian Academy of Forensic Medicine. 33: 330-334.

Sagah GA, Oreby MM, El-Gharbawy RM et al., (2015): Evaluation of potential oxidative stress in egyptian patients with acute zinc phosphide poisoning and the role of vitamin $\mathrm{c}$. Int $\mathrm{J}$ Health Sci (Qassim). 9: 375-385.

Schonwald S (2001): Medical toxicology. A synopsis and study guide. Lippincott Williams and Wilkins, Philadelphia, PA, pp: 117-120.
Shadnia S and Soltaninejad K (2011): Spontaneous ignition due to intentional acute aluminum phosphide poisoning. J Emerg Med. 40: 179181.

Shadnia S, Rahimi M, Moeinsadat M et al., (2006): Acute methemoglobinemia following attempted suicide by dapson. Arch Med Res. 37: 410-414.

Shadnia S, Sasanian G, Allami P et al., (2009): A retrospective 7-years study of aluminum phosphide poisoning in tehran: Opportunities for prevention. Hum Exp Toxicol. 28: 209-213.

Shadnia S, Soltaninejad K, Hassanian-Moghadam H et al., (2011): Methemoglobinemia in aluminum phosphide poisoning. Hum Exp Toxicol. 30: 250-253.

Shahin MM, Abuelfadl AA and Zaki ANM (2016): The potential role of $s-100 \beta$ protein in evaluation of CNS affection and prediction of mortality in acute phosphides intoxication. Ain Shams Journal of Forensic Medicine and Clinical Toxicology. 26: 7-15.

Singh S, Bhalla A, Verma SK et al., (2006): Cytochrome-c oxidase inhibition in 26 aluminum phosphide poisoned patients. Clin Toxicol (Phila). 44: 155-158.

Soltaninejad K, Nelson LS, Khodakarim N et al., (2011): Unusual complication of aluminum phosphide poisoning: Development of hemolysis and methemoglobinemia and its successful treatment. Indian J Crit Care Med. 15: 117-119.

Sood AK, Mahajan A and Dua A (1997): Intravascular haemolysis after aluminium phosphide ingestion. J R Soc Med. 90: 47-48.

Srinivas R, Agarwal R, Jairam A et al., (2007): Intravascular haemolysis due to glucose-6phosphate dehydrogenase deficiency in a patient with aluminium phosphide poisoning. Emerg Med J. 24: 67-68.

Stewart A, Whiteside C, Tyler-Jones V et al., (2003): Phosphine suicide. Chemical Incident Rep. 27: 23-26.

Vijayanath V, Anitha MR, Raju GM et al., (2011): Forensic view on aluminium phosphide poisoning. Journal of Indian Academy of Forensic Medicine. 33: 289-291. 


\section{الملخص العربي}

\section{الميتهيموجلوبينيميا وتحلل الدم داخل الأوعيةالدموية: مظاهر غير عادية للتسمم بالفوسفايدات المعدنية}

\section{أميرة أمين وهدان و إيناس إبراهيم المداح 1}

المقدمة:الفوسفايدات المعدنية هي مبيدات حشرية ومبيدات للقوارض فعالة للغاية .وهي تستخدم كمبيد رخيص وفعال للقوارض في البلدان النامية. تحلل الدم والميتهيموجلوبينيميا هي مضاعفات نادرة ولكنها مذكورة للتسمم بالفوسفايد

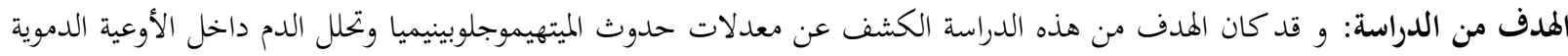
في بعض حالات التسمم الحاد بالفوسفايد.

المرضى والطرق :أجريت هذه الدراسة المقطعية على 50 حالة يعانون من التسمم الحاد بالفوسفاتيدات المعدنية و الذين تم دخولهم المى وحدة

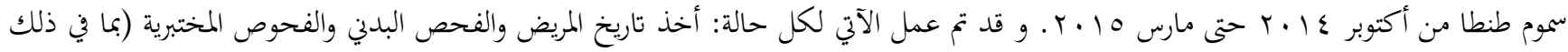

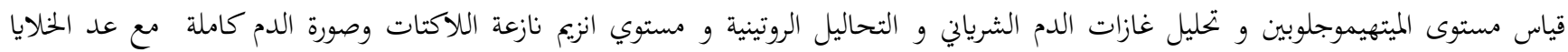
الرتيكيولوسيتية.

النتائج: عانت ثماني حالات (7 ( ٪) من الميتهيموجلوبينيميا وتحلل الدم مجتمعين. كان فوسفيد الألومنيوم هو العنصر السام في سبع منها وفوسفيد الزنك في واحدة فقط. وقد عانت ثلاث حالات (7٪) من الميتهيموجلوبينيميا وحدها، واحد منهم فقط تسمم بفوسفيد الألومنيوم والاثنين

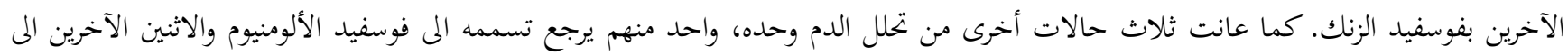

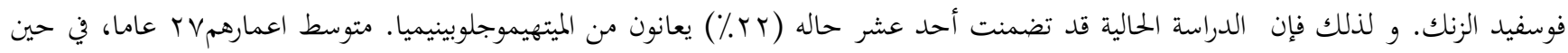

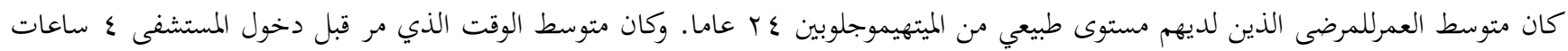
بالنسبة لحالات الميتهيموجلوبينيميا وساعتين في المرضى الذين لديهم مستوى طبيعي من الميتهيموجلوبين مع فارق ذو دلالة إحصائية بين كل منهما. وكان

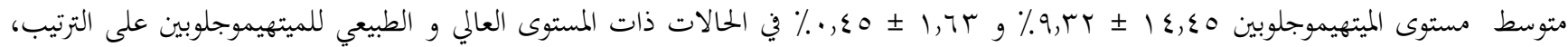

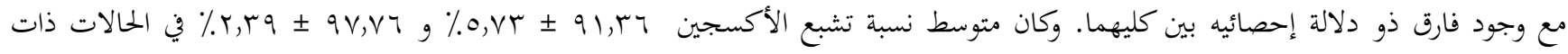

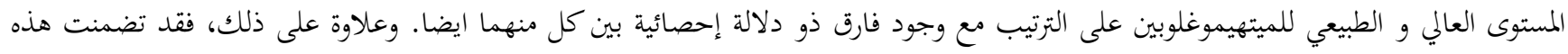

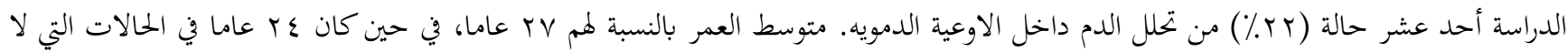
تعاني من تحلل في الدم. ومتوسط الوقت الذي مر قبل دخول المستشفى كان r ساعات في حالات تحلل الدم و ساعتين في الحالات التي لا تعاني من

الاستنتاج: تم التوصل إلى أن الميتهيموغلوبينيميا و تحلل الدم يمكن أن يعقد مسارحالات التسمم الحاد بالفوسفايد.

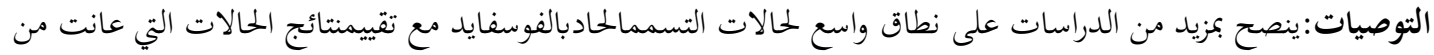
الميتهيموجلوبينيميا و تحلل الدم وتقييمفعاليةالعلاجالمتاح لمثلهذهالحالات. علاوة على ذلك فمن المهم ان يكون خبراء الحذدمة الطبية على علم بهذه المظاهر النادرة للتسمم بالفوسفايد. الكلمات الرئيسية: فوسفيد الألمنيوم، فوسفيد الزنك، التسمم، الميتهيموجلوبينيميا ، تحلل الدم. 